\title{
Threats to the ocean: on the role of ecosystem approaches to fisheries
}

\author{
Villy Christensen ${ }^{1,{ }^{*}}$, Karl A. Aiken $^{2}$, Maria C. Villanueva $^{3}$
}

\author{
${ }^{1}$ UBC Fisheries Centre and North Sea Centre, 2202 Main Mall, Vancouver BC, Canada V6T $1 Z 4$ \\ ${ }^{2}$ Life Sciences at the University of the West Indies, Mona Campus, Jamaica \\ ${ }^{3}$ Halieutic Resources Laboratory of IFREMER at Port-en-Bessin, FRANCE \\ *: Corresponding author : Villy Christensen, email address : v.christensen@fisheries.ubc.ca
}

\begin{abstract}
:
It is becoming increasingly clear that humans impact marine ecosystems and their biodiversity to a very considerate degree, and evidence of the scale of impact is growing. An enabling factor for this has been a change in focus from local-level studies to increased emphasis on meta-analysis of global or regional-level analysis of fisheries' impact. Results include the facts that the world's total fish catches have been decreasing over the last decade or more; that larger, predatory fishes (table fish) are becoming increasingly scarcer; and that we are appropriating the ocean shelves' primary productivity to the same level as we are for terrestrial ecosystems. Ecosystems are being eroded in countries throughout the world, and though one might get the impression from the IUCN Red List that it is mainly a developed-country problem, it is alarming that the impact of severe overfishing may be on an even larger scale for developing countries. We describe aspects of the risks overfishing poses to marine ecosystems, and point out how ecosystem approaches to fisheries can be used to evaluate the potential impact of alternative fishing policy scenarios.
\end{abstract}

Keywords: Ecosystem-based management of fisheries • Ecosystem modeling

\section{Résumé:}

Il devient de plus en plus clair que les activités humaines altèrent les écosystèmes marins et leur biodiversité à un degré considérable, et les preures de l'échelle des impacts anthropiques s'accumulent. Un des facteurs déterminants de cette prise de conscience réside dans le changement d'échelle des études de l'impact des pêches qui sont passées d'un niveau local à un niveau global ou régional au travers d'études de type méta-analyse. Les résultats obtenus les plus évocateurs incluent le fait que la totalité des captures mondiales de poissons a diminué pendant la dernière décennie ou plus; que les grands prédateurs ('essentiel des poissons "de table") deviennent de plus en plus rares; et que nous nous approprions la productivité primaire des plateaux continentaux au même titre que nous nous sommes appropriés celle des écosystèmes terrestres. Les écosystèmes sont érodés dans les pays du monde entier, et bien que la liste rouge de l'IUCN laisse penser que c'est principalement le problème des pays développés, il est alarmant de constater que l'impact de la surpêche excessive pourrait être une échelle bien plus grande encore pour les pays en voie de développement. Nous décrivons certains aspects des risques que pose la surpêche pour les écosystèmes marins, et mettons en exergue comment l'approche écosystémique des pêches peut être employée pour évaluer l'impact potentiel de scénarios alternatifs de règlementation des pêches.

Mots clé: Gestion écosystémique des pêcheries - Modélisation écosystémique 


\section{Introduction}

Lord Byron wrote these lines two hundred years ago, at a time where humans indeed had no control of, and but little impact on the oceans. That view was still dominant a century later when Sir Thomas Huxley, President of the Royal Society, at the opening of the 1882 London Fisheries Exhibition stated that "the most important sea fisheries, such as the cod fishery, the herring fishery, and the mackerel fishery, are inexhaustible ... the multitude of these fishes is so inconceivably great that the number we catch is relatively insignificant". In the beginning of the $20^{\text {th }}$ Century when the North Atlantic fisheries became mechanized perceptions gradually started to change, and evidence of declining catch rates led to the creation of fisheries research institutions throughout the North Atlantic area; institutions created with emphasis on studies of marine production systems (Rozwadowski, 2002).

The 1960s saw industrialized fisheries spreading through the developing world as part of 'development' projects, quickly followed by major declines in catch rates for the longer-lived fish species, notably of the larger sharks, rays and bottom fishes (Pauly, 1979). Hand in hand with this, increased fishing pressure in many places led to a break-down of traditional management structures where such were established, followed by open access to the fisheries and further effort expansion. In the decades to follow, many fish stocks crashed due to overfishing, often with devastating impact on local fishing communities (Perry and Ommer, 2003).

Yes, many fisheries scientists will argue, still today, that things are fine with the oceans; what we observe (to paraphrase Lord Byron) are merely rolling waves on the ocean surface; natural succession will let species in- or decrease, and even if we fish down one species, another will pop-up from the food web, and replace it in the ecosystem. In some cases it may even be economically beneficial (when not considering social costs) - extensive shrimp fisheries appearing as cod were depleted for a while made landings in eastern Canada exceed the value from when cod-fisheries were dominant. Nature is resilient, we do not 
control it, and what's more, the control on fishing practices put in place in notably developed countries since the 1970s is beginning to have an impact. Things are fine apart from a few, unfortunate cases, where stock may have plummeted. And what's more, some of these unfortunate cases are indeed not the deed of humans, but rather an act of God or Gaia through environmental variability.

We are facing two major issues when trying to evaluate the virtue of the two diverging point-of-views outlined above,

- What is the evidence for fisheries having had major impact on species abundance at the ecosystem level? Does the impact of fisheries go beyond local impact on individual species?

- What is the relative role of fisheries and of the environment for the population trends of species of concern (typically threatened charismatic species, or depleted commerciallyimportant fish species)?

We will present results from a series of recent studies conducted at the regional and global level and with the purpose of evaluating how ecosystems have been impacted by humans through fisheries. We further consider how ecosystem modeling can be used to evaluate options for ecosystem recovery, notably by incorporating ecological, economical and social considerations.

Further, we will describe how recent developments in ecosystem modeling have enabled studies aimed at evaluating how ecosystems components are impacted by changes in system productivity and fishing pressure. The ecosystem modeling in question is an important tool for the movement toward ecosystembased management of fisheries that is currently taking place in countries throughout the world as a consequence of the international agreements reached in Kyoto, Johannesburg, Rome and Reykjavik. We will describe some of the key assumptions behind the ecosystem modeling, as well as the capabilities of the modeling. Notably, we focus on how ecosystem modeling can be used to evaluate alternative scenarios for fisheries management, both in the context of current management practices and for global outlook related to food supply and security. 
The studies we refer to are drawing heavily on results from the Sea Around Us project at the University of British Columbia; a project that the current authors either participate directly in, or cooperate with.

\section{Human impact on marine ecosystems}

There are surprisingly few analyses of the global status of fish and fisheries. Prospects for the potential fish production from the oceans have varied widely, from levels of around 70 million tons up to several times higher (Pauly, 1996). For as long as the fisheries were expanding and catches kept increasing, estimations were essentially a guessing-game, and indeed they have never reached any noteworthy level of sophistication. Unfortunately, this situation has changed; unfortunately because the world's fish capture production has stopped increasing and has leveled off at around 70--80 million tons annually; indeed, it may have been decreasing since around 1990 (Watson and Pauly, 2001). The implication of this is that if we do not improve management of our fish resources, we must expect catches to decrease in the future, not increase (Hilborn, Branch, Ernst, Magnusson, Minte-Vera, Scheuerell and Valero, 2003).

\section{Figure 1 Near here}

Aquaculture has often been heralded as the savior for the world's fish supply. We fear though that as long as aquaculture keeps emphasizing the farming of high-trophic level species (Pauly, Tyedmers, Froese and Liu, 2001), and as long as suitable replacements for fish-based feeds have not been found, the contribution of aquaculture will rather be more toward habitat-degradation and privatization of public resources than to food security.

One can question if the decreasing catch levels are due to fisheries management finally being successful at controlling fishing effort, i.e. if what we observe is a reduction in fishing effort at the global level as part of a rebuilding of fish populations. While global attempts at evaluating fishing effort are sparse, a new study indicates that global nominal effort levels (measured in horsepower-days) for port-based 
fisheries (excluding tuna and distant water fleets) annually increased with $2.8 \%$ in the 1970 s, with $3.0 \%$ in the 1980s, and with $1.5 \%$ in the 1990s (Gelchu, 2006). Estimating effective effort the increases are even more pronounced at $7.5 \%, 7.6 \%$ and $6.1 \%$ annually for the three decades, respectively. We may conclude that the decreasing catch levels are highly unlikely to be caused by reduced effort in the fisheries, every indicator we know of tells us that it is business as usual in the world's oceans. Effort keeps increasing and stocks decreasing.

\section{Fishing down marine food web}

As fisheries develop in an area their target species change. During their initial development, the focus is usually on higher-trophic level species. As these become more scarce attention changes toward the more abundant prey species, and ultimately concentrates on lower-trophic level species, e.g., shrimps and squids (Christensen, 1996; Pauly, 1979). This process, now known as 'fishing down the food web'

(Pauly, Christensen, Dalsgaard, Froese and Torres, 1998), and its global nature has been demonstrated in numerous studies throughout the world.

Fishing down the food web results initially in increasing catches, but catch levels eventually stagnate or decline, while the trophic levels of the catches continue to decline. The effect is clearly distinguishable on a decadal scale, and the trends are so pronounced that they raise considerable concern for the sustainability of today's fisheries under present management regimes.

Fishing down the food web leads to loss of diversity at the ecosystem level. In many systems, top predators are now very much depleted due to targeted fisheries and the limited ability of long-lived top predators to withstand high fishing pressures (Myers and Worm, 2005).

In most developing countries there is limited capacity to consider long-term biodiversity issues - the immediate welfare and nutrition of the population take precedence. The dilemma made apparent through 
the fishing down the food web studies, however, has direct implications for what can be extracted from the seas: overexploitation leads to dwindling catches, and the catches are of a lower value, as trophic levels and prices often are correlated.

The Conference of Parties of the Convention on Biological Diversity in 1995 drew up the Jakarta Mandate, which outlines actions for preservation of biodiversity and, in agreement with the Kyoto Conference on Food Security, places emphasis on the need for integrated approaches for management of marine and coastal ecosystems. With the recent Johannesburg Declaration on Sustainable Development a commitment has been reached to rebuild stocks by 2015 , and together this calls for development of ecosystem-based approaches to fisheries management.

\section{Threats to biodiversity}

The Johannesburg Plan of Action recognizes overfishing as a major global problem calling for swift action aimed at restoration of depleted resources and sustainable exploitation. Overfishing and other anthropogenic impacts in turn raise concerns for biodiversity. Loss of biodiversity is related to overexploitation and habitat degradation, both of which are widespread problems in the coastal zones of the world. It has been estimated that half the world's salt marshes may have been lost, one third of the world's mangroves lost (Alongi, 2002), and 20\% of corals reefs destroyed and of the remaining, half are under threat of destruction (Wilkinson, 2004).

Where it has been a general assumption among scientists that extinction of marine species due to exploitation is unlikely (Malakoff, 1997), growing evidence points to a need for revision of this assumption (Dulvy, Sadovy and Reynolds, 2003). Extinction has been reported for a growing number of fish populations (Myers and Worm, 2005), and there is fear that even species diversity may be at risk for a number of species with limited ranges (Roberts, Hawkins, Chapman, Clarke, Morris, Miller and 
Richards, 1998). As a fishery develops, mean size and age of fish decline in the exploited populations. There is selection for early maturity and for small females, which can lead to genetic change, including loss of genetic diversity within - case studies indicate effects within 10--20 generations (Conover and Munch, 2002; Smith, 1999).

The greatest threat to diversity among fishes is for freshwater species. Many species have been lost in recent decades, notably through habitat degradation rather than through fishing. As a result, $90 \%$ of the fish species on the IUCN Red List of endangered and threatened species are either freshwater or estuarine, and freshwater fish species are ten times more likely to be threatened than marine species (Froese and Torres ,1999).

The minimal representation of marine species on the International Union for the Conservation of Nature and Natural Resources (IUCN) Red List in large part reflects our level of knowledge about the threats to marine life. Of the marine fish species that are actually included on the Red List around half occur in the USA Continental States. This overrepresentation further highlights the necessity of conducting biodiversity research at the global scale.

\section{Trends of marine fish abundance}

One aspect illustrated through the above discussion on biodiversity is that spatial information is needed. The tool for this, GIS (Geographical Information System) was initially developed for national land inventory during the early 1960s, and it was not until the 1980s that this application was demonstrated to be useful in aquatic systems (Valavanis, 2002). Since then, GIS has become a major tool in oceanography, fisheries and marine ecology providing not only descriptive but also predictive images once coupled with other techniques such as geostatistics and generalized additive models (Matheron, 1971; Rivoirard, Simmonds, Foote, Fernandes and Bez , 2000). It has resulted in considerable 
contributions in fisheries management in terms of predicting stock distribution, abundance, habitat preferences and productivity assessments (Fisher and Toepfer ,1998; Rivoirard, Simmonds, Foote, Fernandes and Bez, 2000; Wright, 1999).

\section{Figure 3 near here}

Recently, global mapping of fish abundance implemented by the Sea Around Us project, and made available online at www.seaaroundus.org focused on combining GIS application with predicted distributions in spatial models to determine "how much fish is still left out there?" The massive decline in biomass of high trophic-level fishes over time in has been illustrated by the analyses of Christensen et al. (2003a) for the North Atlantic (Figure 3), the South China Sea and West Africa. Fisheries in the northern Atlantic represented in Figure 3 reached their maximum production levels several decades ago and are now showing a declining trend in total catches (Pauly, Christensen, Guénette, Pitcher, Sumaila, Walters, Watson and Zeller, 2002). The declining catches and the biomass trends indicated by the figure are consistent with observations that these areas have the highest incidence of overexploited, depleted or slowly recovering stocks that have been depleted by overfishing (Pauly and Maclean, 2003). In fact, this phenomenon is not specific to the Atlantic as an emerging pattern shows worrying global decline for larger, long-lived species (Myers and Worm, 2005).

\section{Shifting baselines and sustaining present misery}

It is clear that if the present catch levels are to be sustained, or perhaps even improved, the avenue will be through improved management of marine resources, not through expansion of fisheries for underexploited resources or the building of bigger fleets (Garcia and Grainger, 2005; Hilborn, Branch, Ernst, Magnusson, Minte-Vera, Scheuerell and Valero, 2003; Pauly, Watson and Alder, 2005). The management strategies must include consideration of the ecosystem interactions, form and functioning, including the role of the 
top predators (Christensen, 1996), and it has been suggested that marine ecosystems may yield considerably more than the present catch levels if stocks were rebuilt to their pre-impact levels (Christensen and Pauly, 1998; Pauly and Christensen, 1996). This had led to a series of ecosystem restoration studies aimed at describing historic ecosystems and how best to exploit such systems using the Ecopath with Ecosim (EwE, www.ecopath.org) approach as the enabling tool and based on a variety of information from a wide-ranging set of disciplines (Ainsworth, 2006; Pitcher, 2005; Pitcher, Heymans, Ainsworth, Buchary, Sumaila and Christensen, 2004). This indeed raises the issue that the goal for fisheries management should be rebuilding of ecosystems, not what is termed 'sustainability' if this merely infers sustaining a severely depleted level (Pauly, 1995; Pitcher and Pauly, 1998).

\section{Who did it? Evaluating human and environmental impact}

Ecosystems are vulnerable to natural- and human-induced changes and their combined effects are often difficult to disentangle. While humans are not always the sole contributor to environmental degradation, damage inflicted by humans is often of a drastic, perhaps even irreversible, character. Freshwater and marine habitats are being destroyed by pollution, infrastructure development, and human settlements. A compelling adaptation on how humans can change the course of ecosystem evolution was presented through the 2004-film about Lake Victoria, "Darwin's nightmare” by Hubert Sauper. Though heavy predation of cichlids by the introduced Nile tilapia combined with heavy fishing have ended up in depleted stocks and biodiversity loss (Pitcher and Hart, 1995), one cannot say that the ecosystem would have 'survived' longer in the absence of the stress inflicted by the Nile tilapia.

Numerous problems put forward in this paper, concerning the overexploitation of marine biological resources, must be solved. It is apparent that human activities out-run a sense of co-habitation as environments are exploited beyond the sustainable. Placing price tags on aquatic resources have made humans the most cunning and innovative prey hunters. Excessive fishing pressure has resulted not only in 
a loss in total production, but has also had a significant social and economic impact. This ends up in a world becoming a single enterprise where resources, such as in the fishing industry, are 'free' goods, endlessly exploited for human investment.

There is therefore, growing public concern regarding the declining condition of the world's aquatic environment as a consequence of the impact of human activities. This concern has resulted in increasing pressure on decision makers to establish new and innovative policies that can be deployed in order to reverse those negative trends. Currently, establishment of marine protected area is becoming one of the management tools needed in order to achieve policy goals (Roberts, Hawkins and Gell, 2005).

Management of marine resources is a complex undertaking, and the scientific knowledge required for a cross-sector approach that integrates environmental, socioeconomic, and developmental requirements is often lacking or unavailable to policy makers. We have, however, seen progress in ecosystem modeling in recent years that seeks to enable such multi-sector approaches. Underlying this is that ecosystem modeling is now reaching a state where it is able to produce plausible simulations of the impact caused by fisheries, ecosystem and environmental impact factors (Christensen and Walters, 2005).

An example of this is an ecosystem modeling study of how threatened Steller sea lions have been impacted by the combined effects of fishing, predation, competition, and ocean productivity in the Aleutian Islands and the eastern Gulf of Alaska (Guénette, Heymans, Christensen and Trites, 2006). Numerous studies have attempted to find the cause of Steller sea lion decline, but no clear explanation has emerged in spite of very extensive research activities and expenditures reaching into the hundred million dollar price range. The modeling indicated that it was possible to replicate the changes in sea lion population size as well as of most other ecosystem groupings, but that this was only possible if including the combined effects of the major drivers that impact sea lion abundance. Also, the relative impact of these drivers could be quantified, leading to killer whale predation and ocean productivity patterns being found the most important, followed by fishing, and competition with flatfish. 
This study clearly illustrates how ecosystems are impacted by multiple forces, and that it is necessary to consider more than just the 'usual suspects' if we are to improve our understanding and management of marine resources. The study is also a good example of one of the most important achievements that has been reached in ecosystem modeling in recent years, the capability to simulate and reproduce the recent ecosystem history. This has by now been done this for more than two dozen systems (Christensen and Walters, 2005), and we emphasize that the capability of ecosystem models to replicate trends of abundance, productivity and exploitation in ecosystem represents a major step forward for the modeling. During the years of the International Biological Program (1964--1974) considerable effort was allocated to establishing systems ecology as a discipline, and while this succeeded, a major undertaking of the system ecologists, to construct ecosystem models that could be used to simulate changes in ecosystem as response to anthropogenic and environmental factors never did. This led to most of the practitioners in the field eventually abandoning ecosystem modeling, and it was only with Carl Walters' formulation of the 'foraging arena' that clear progress was achieved (Walters and Juanes, 1993; Walters and Martell, 2004). Notably, it has made it possible to produce well-behaved models capable of reproducing trends in ecosystems, and subsequently to evaluate how multiple drivers impact ecosystems (as illustrated by the Steller sea lions), and to conduct the modeling in a well-structured data management and parameter estimation system in form of the Ecopath with Ecosim modeling software (Christensen and Walters 2004a).

The possibly most important finding from the modeling is that in order to understand what is happening in the oceans we need to consider how ecosystems are impacted by environmental as well as by anthropogenic factors. Changes in primary productivity have strong impact at all trophic levels in ecosystems. This in turn, links fisheries to climate change research, and notably underlines the importance of the numerous activities that are now starting up to link marine ecosystem and climate change modeling. 


\section{Scenario modeling}

The newly-developed capabilities of ecosystem modeling to reproduce historic trends in ecosystems open them to being used to explore scenarios. While there is no guarantee that the fit to historic trends is obtained for the right reason (Essington, 2004), we know that the parameter settings and the model formulation used for such a model is at least done so that its reaction to the major ecosystem drivers (notably fisheries and environmental effects) are plausible. Thus we see that a minimum requirement for a model to be used for scenario modeling is that it should be well-behaved enough to reproduce historic trends. Simulation modeling related to fisheries and based on these premises has mainly been on two fronts; exploring policy options and exploring scenarios for future states of ecosystems. We will discuss each of these.

\section{Optimum policy exploration}

A number of studies have explored how to allocate effort among fleets (or 'metiers') so as to maximize a given objective function, see, e.g., Christensen and Walters (2004b). While the modeling aspects of this are fairly simple (Walters, Christensen and Pauly, 2002), the analysis highlighted the important question of how to best define and agree on an objectivity function for desired development. Ideally, the objectivity function should represent society's interest, but rarely is there an omnipotent ruler to make decisions on such matters. More often diverging interests between stakeholders have to be considered, precluding overall maximization.

In the EwE approach, the policy exploration is done by defining an objectivity function with four components, involving optimization of 
- $\quad$ profit from fisheries;

- value of fisheries or number of jobs in the fisheries;

- 'ecosystem structure';

- mandated rebuilding.

Of these the profit from the fishery is calculated based on predicted catch and price of catch by fleet category. The second objective, value of the fisheries or jobs in the sector assumes that the number of jobs can be expressed as a relative number for a given fleet category, e.g., that the artisanal canoes will have 5 jobs per $\mathrm{X}$ dollars of income while the industrial trawlers may have 2 jobs per $\mathrm{X}$ dollars of income. This objective provides a link to social considerations, and calls for research on how best to evaluate how many jobs are created for each fleet category.

The third objective 'ecosystem structure' maximizes for overall longevity of the populations in the given ecosystem, and is based on the consideration that mature ecosystems will be characterized by long-lived individuals and species (Christensen, 1995). The last objective, mandated rebuilding is used to incorporate legal constraints, (e.g., certain restrictions are in place until a given species has recovered to a defined level) or simply minimum acceptable biomasses (MBAL) for given species.

The policy explorations underline the importance of valuing fisheries and ecosystem services from multiple angles. When taking a narrow approach, placing emphasis on only one of the components of the policy objectivity function the expected result is often of a drastic nature with either the social component or the ecosystem suffering (Christensen and Walters, 2004b). Emphasizing value of the catch only (as has most often been the case for fisheries anywhere) leads to drastic changes in the ecosystem structure, with long-lived species being fished out, and the ecosystem shifted toward dominance of low-trophic level, high-value species, notably shrimps. Alternatively, emphasizing ecosystem structure leads to nearcomplete closure of the fisheries, possibly combined with selective fishing as part of an ecosystem manipulation scheme. 
The optimizations do, however, typically lead to more sensible solutions when a balanced approach is taken, indeed there may be win-win situations where all or at least the majority of the parties involved would benefit (Christensen and Walters, 2004b). The results also highlight that there are trade-offs involved in managing at the ecosystem level. Indeed, we cannot expect that the maximum sustainable yield from an ecosystem perspective corresponds to the sum of maximum sustainable yields that are estimated by optimizing for each of the ecosystem populations using standard single-species maximum sustainable yield (MSY) methodologies (Walters, Christensen, Martell and Kitchell, 2005). Typically, we find that MSY will be higher for low-trophic level species, (which benefit from predation release when their predators are fished), and lower for high-trophic level species, (which will have poorer feeding conditions when their forage species are depleted through exploitation).

An important aspect of the policy explorations is that they emphasize the need for properly evaluating the cost of fisheries. In addition to the more straightforward aspect of evaluating direct cost of fishing we need to consider indirect effects, both socially and for the ecosystem. The social aspect calls for understanding of social interactions and values, while the ecosystem aspect calls for ecological considerations of direct and indirect effects of fishing. Up to now, there has been little work attributed to jointly examining all of these factors, i.e. of the overall cost of fishing in an ecosystem context, and we note that this is an area where the European Community-funded project ECOST has an important contribution to make.

\section{Future modeling}

A major, recently completed international initiative, the Millennium Ecosystem Assessment, (MA), was launched by the UN Secretary General with the aim of providing a scientific assessment of the health of the world's ecosystems (www.millenniumassessment.org). The work involved fourteen hundred scientists from around the globe cooperating over a five-year period, and among other included a component aimed 
at exploring scenarios for future development, including for fisheries (Pauly, Alder, Bennett, Christensen, Tyedmers and Watson, 2003).

The MA scenario work, and its follow-up through the United Nations Environment Programme (UNEP) GEO-4 Report Series, uses a standardized set of scenarios for analyzing complex systems in an attempt to predict the possible outcomes. The scenarios for how to manage ecosystem services include,

- Global Orchestration; assuming socially conscious globalization, with emphasis on equity, economic growth, and public goods, reacting to ecological problems when needed;

- Order from Strength; a regionalized approach with emphasis on security and economic growth, responding to ecological problems as required ;

- Adapting Mosaic; also regionalized, but more proactive with regards to ecosystem management, and including local adaptations and flexible governance;

- TechnoGarden; a globalized approach relying on green technology and with a proactive approach to ecosystem-based management.

\section{Figure 7, Near here}

The part of this scenario modeling that deals with marine systems are using EwE models to explore how ecosystems and the fisheries relying on them may react to policy interventions providing external pressure on the resources. This work is currently being expanded through funding from UNEP and the Netherlands Ministry of the Environment to provide regional examinations of how future fish supply is likely to be impacted by the four scenarios. We expect this work may impact future policy settings in many areas.

\section{Outlook}

Marine ecosystems are impacted by a multitude of factors and they have been exploited to the degree that overall productivity has started to decline. This along with concern for biodiversity in the oceans has 
prompted the development of an integrated approach towards the management of biological resources. Monitoring system productivity requires sufficient knowledge on how species interact, respond and adapt to varying environmental conditions. Single-species modelling has led to inconsistencies and discouraging results as underlying assumptions have been violated. The question 'what is the future of the World's fisheries' can not be fully explored by a single scientific discipline. The complexity of managing fisheries resources using ecosystem modeling relies on consideration of uncertainty with regard to numerous aspects: spatio-temporal changes in species abundance, parameters considered, varying dynamics of fishing effort, and unpredictable future environmental and economic conditions to mention but some. We consider ecosystem modelling an important and necessary tool to this aim, and note that recent developments in the field has improved modeling capabilities to the degree that it can now be of direct use for fisheries management and for exploring sustainable scenarios for future development (Christensen and Walters, 2005).

We note, indeed emphasize, though that while ecosystem modeling is an important tool, it is but that. If fisheries management is to become more successful the key is to understand the human dimension of the management. A participatory consensual approach to management involving all players is necessary (see, e.g., Aiken, Kong, Smikle, Mahon and Appeldoorn, 1999) and emphasis must be given to how best to develop such management. This is, however, a topic that is well-covered in the present journal and elsewhere in the literature, and we refer to other studies for further treatise.

Indeed it is clear that sustainability programs have failed due to limiting efforts on discipline-specific processes and the absence of interactive engagements with other scientific disciplines. Frequently, conventional ecological methods and institutional arrangements fail to recognize the influence of anthropogenic forces or other dimensions such as those concerning biophysical or socio-political issues in ecosystem development and evolution. As ecosystem function reacts as a consequence of environmental changes and human activity, this shows that biological, social and economical incentives can not be readily separated and a continuous education combined with ethical concern are imperative towards 
ecosystem conservation. Integrating community-based research and ecosystem management based on social learning and transdisciplinary inquiry is significant in the quest to conserve global biological resources (McMichael, Butler and Folke, 2003).

This is quite a difficult task, in a practical point of view, due to several underlying factors such as conflicting interests in different scientific disciplines, process of effective public inclusion and the coherence of these approaches to existing institutional management schemes. It is only adequate to assume that ecosystem modelling needs to define critical values and risk-prone conditions in collaboration with managers and stakeholders. The need for a 'precautionary' approach in ecosystem modelling can mitigate 'shocks' due to unpredictable changes following intensive exploitation. This approach captures the idea that scientific methods should be combined with societal values to protect global commons.

Villy Christensen is an ecosystem modeler and Associate Professor at University of British Columbia. His work is focused on developing methodologies for ecosystem based management of marine resources, and he is developing the widely applied Ecopath with Ecosim modeling approach. He also analyzes global impact of fishing as part of the Sea Around Us project at UBC. Recent publications include a special issue of Ecological Modelling (172(2-4) with J. Maclean) Placing Fisheries in their Ecosystem Context (2004); (with C.J. Walters) "Trade-offs in Ecosystem-scale Optimization of Fisheries Management Policies", Bulletin of Marine Science 74(3):549-562 (2004); and (with D. Pauly, J. Alder, E. Bennett, P. Tyedmers and R. Watson) "Future of Fisheries", Science 302/5649:1359-61 (2003). Authors' address: UBC Fisheries Centre and North Sea Centre, 2202 Main Mall, Vancouver BC, Canada V6T 1Z4 [E mail: v.christensen@ fisheries.ubc.ca]; 
Karl A. Aiken is a Lecturer in Life Sciences at the University of The West Indies, Mona Campus, Jamaica, and his research focuses on fisheries biology and approaches for ecosystem-based management of fisheries resources. Recent publications include articles in Proc. Gulf Caribb. Fish. Inst. (2001) "Aspects of reproduction, age and growth of the Lane Snapper in Jamaican coastal waters" (52 : 116-134), (with Kong, G.A., Smikle, S., Mahon, R. and Appeldorn, R) in Ocean and Coastal Management (1999) “The queen conch fishery on Pedro Bank, Jamaica: discovery, development, management” (42 : 1069-1081.) and in Environ. Biol. Fishes. (1998) "Reproduction, diet and population structure of the mountain mullet, Agonostomus monticola in Jamaica, West Indies" (53 : 347-352). Author's address: University of the West Indies, Mona Campus, Kingston 7, Jamaica [email: kaaiken@uwimona.edu.jm];

Maria Concepcion Villanueva is a post-doctoral fellow based in the Halieutic Resources Laboratory of IFREMER at Port-en-Bessin (France). Her scientific interests focus on fisheries ecology and management through ecosystem modeling. Recent publications include articles in Ecological Modelling "Trophic Relationships in the New Bagre Man-made Lake as Described by Using Ecopath: Possible Influence of Siltation on the Evolution of the Ecosystem" (191 : 243-59 with M. Ouedraogo and J. Moreau); "Comparing Energy Fluxes and Trophic Dynamics of Two West African Coastal Lagoons (197 : 461-77, with P. Lalèyè, J.-J. Albaret, R. Laë, L. Tito de Morais and J. Moreau) and in Living Aquatic Resources on "Diel-feeding, Periodicity, Daily Ration and Relative Food Consumption in Indigenous Fish Populations in Three Reservoirs of Sri Lanka (19: xx-xx with W.S. Weliange, U.S. Amarasinghe and J. Moreau), all released in 2006. Author's address : Laboratoire Ressources Halieutiques - IFREMER 1, Avenue du Général de Gaulle BP 3214520 Port-en-Bessin, France. [Email : Ching.Villanueva@ifremer.fr]

Maria C. Villanueva: IFREMER [email: ching.villanueva@ifremer.fr]. 


\section{References}

Aiken, K. A., Kong, G. A., Smikle, S., Mahon, R. and Appeldoorn, R. (1999) "The Queen Conch Fishery on Pedro

Bank, Jamaica: Discovery, Development, Management", Ocean and Coastal Management 42/12: 1069-81.

Ainsworth, C. (2006) "Strategic Marine Ecosystem Restoration in Northern British Columbia", in C. Ainsworth

Resource Management and Environmental Studies . Vancouver: University of British Columbia (Ph.D. thesis, 422

pp.)

Alongi, D. M. (2002) "Present State and Future of the World's Mangrove Forests", Environmental Conservation 29: $331-49$.

Christensen, V. (1995) "Ecosystem Maturity - Towards Quantification", Ecological Modelling 77(1) (Jan): 3-32.

Christensen, V. (1996) "Managing Fisheries Involving Predator and Prey Species', Reviews in Fish Biology and Fisheries 6(4)(Dec): 417-42.

Christensen, V., Amorim, P.A., Diallo, I., Diouf, T., Guénette, S., Heymans, J.J., Mendy, A.N., Ould Taleb Ould Sidi, M. M., Palomares, M.L.D., Samb, B., Stobberup, K.A., Vakily, J.M., Vasconcellos, M., Watson, R. and Pauly, D. (2004) "Trends in Fish Biomass off Northwest Africa, 1960-2000", in IRE (France) (ed) Marine Fisheries, Ecosystems, and Societies in West Africa: Half a Century of Change, pp. 377-86. (IRE, France)

Christensen, V., Guénette, S., Heymans, J. J., Walters, C. J., Watson, R., Zeller, D. and Pauly, D. (2003a) "Hundredyear Decline of North Atlantic Predatory Fishes', Fish And Fisheries 4( (Mar): 1-24.

Christensen, V. and Pauly, D. (1998) "Changes in Models of Aquatic Ecosystems Approaching Carrying Capacity", Ecological Applications 8 : S104-S09.

Christensen, V. and Walters, C.J. (2005) "Using Ecosystem Modeling for Fisheries Management: Where are We? " ICES C.M. M:19.

Christensen, V., Garces, L. R., Silvestre, G. T. and Pauly, D. (2003) "Fisheries Impact on the South China Sea Large Marine Ecosystem: a Preliminary Analysis Using Spatially-Explicit Methodology", in G.T. Silvestre, L.R. Garces, I. 
Stobutzki, M. Ahmed, R.A. Valmonte-Santos, C.Z. Luna, L. Lachica-Aliño, P. Munro, V. Christensen and D. Pauly (eds) Assessment, Management and Future Directions for Coastal Fisheries in Asian Countries, pp. 51-62. Penang, Malaysia: WorldFish Center Conference Proceedings, 67.

Christensen, V. and Walters, C. J. (2004a) "Ecopath with Ecosim: Methods, Capabilities and Limitations", Ecological Modelling 172(2-4) (2004/3/1): 109-39.

Christensen, V. and Walters, C. J. (2004b) 'Trade-offs in Ecosystem-Scale Optimization of Fisheries Management Policies", Bulletin Of Marine Science 74(3): 549-62.

Conover, D. O. and Munch, S. B. (2002) "Sustaining Fisheries Yields over Evolutionary Time Scales', Science 297(5578) (Jul. 5): 94-6.

Dulvy, N. K., Sadovy, Y. and Reynolds, J. D. (2003) "Extinction Vulnerability in Marine Populations", Fish And Fisheries 4(1): 25-64.

Essington, T. E. (2004) "Getting the Right Answer from the Wrong Model: Evaluating the Sensitivity of Multispecies Fisheries Advice to Uncertain Species Interactions', Bulletin of Marine Science 74(3) (May): 563-81.

Fisher, W. L. and Toepfer, C. S. (1998) "Recent Trends in Geographic Information Systems Education and Fisheries Research Applications at U.S. Universities', Fisheries 23(5): 10-3.

Froese, R. and Torres, A. (1999) "Fishes under Threat: an Analysis of the Fishes in the 1996 IUCN Red List", in R.S.V. Pullin, D.M. Bartley and J. Kooiman (eds) Towards Policies for Conservation and Sustainable Use of Aquatic Genetic Resources, pp. 131-44. Manila: ICLARM (International Center for Living Aquatic Resources Management) Conference Proceedings, 59).

Garcia, S. M. and Grainger, R. J. R. (2005) "Gloom and Doom? The Future of Marine Capture Fisheries", Philosophical Transactions Of The Royal Society B-Biological Sciences 360/1453 (Jan. 29): 21-46.

Gelchu, A. (2006) "Growth and Distribution of Port-Based Global Fishing Effort within Countries EEZs', in Fisheries Centre . Vancouver: University of British Columbia (Ph.D., in preparation). 
Guénette, S., Heymans, J.J., Christensen, V and Trites, A. W. (2006) "Ecosystem Models Show Combined Effects of Fishing, Predation, Competition, and Ocean Productivity on Steller sea lions (Eumetopias jubatus) in Alaska", Canadian Journal of Fisheries and Aquatic Sciences 63: 000-000, in press.

Hilborn, R., Branch, T. A., Ernst, B., Magnusson, A., Minte-Vera, C. V., Scheuerell, M. D. and Valero, J. L. (2003) "State of the World's Fisheries', Annual Review of Environment and Resources 28(1): 359-99.

Malakoff, D. (1997) "Extinction on the High Seas', Science 277: 486-88.

Matheron, G. (1971) The Theory of Regionalized Variables and their Applications . Fontainebleau and Paris: Les Cahiers du Centre de Morphologie Mathématique, Fascicule 5. Centre de Géostatistique.

McMichael, A. J., Butler, C. D. and Folke, C. (2003) "New Visions for Addressing Sustainability", Science 302: 1919-20.

Myers, R. and Worm, B. (2005) "Extinction, Survival or Recovery of Large Predatory Fishes', Philosophical Transactions Of The Royal Society of London B-Biological Sciences 360(1453): 13.

Pauly, D. (1979) Theory and Management of Tropical Multispecies Stocks .Manila: ICLARM (International Center for Living Aquatic Resources Management) Studies and Reviews, 1.

Pauly, D. (1995) "Anecdotes and the Shifting Baseline Syndrome of Fisheries", Trends in Ecology and Evolution 10(10): 430 .

Pauly, D. (1996) "One Hundred Million Tonnes of Fish, and Fisheries Research', Fisheries Research 25(1): 25-38.

Pauly, D., Alder, J., Bennett, E., Christensen, V., Tyedmers, P. and Watson, R. (2003) "The Future for Fisheries', Science 302(5649) (Nov 21): 1359-61.

Pauly, D. and Christensen, V. (1996) "Rehabilitating Fished Ecosystems: Insights from the Past', Naga. Manila 19(3): 13-4. 
Pauly, D., Christensen, V., Dalsgaard, J., Froese, R. and Torres, F., Jr. (1998) "Fishing down Marine Food Webs", Science 279(5352) (Feb.): 860-63.

Pauly, D., Christensen, V., Guénette, S., Pitcher, T.J., Sumaila, U.R., Walters, C.J., Watson, R. and Zeller, D. (2002) 'Towards Sustainability in World Fisheries', Nature 418: 689-95.

Pauly, D., Tyedmers, P., Froese, R. and Liu, L.Y. (2001) "Fishing down and Farming up the Food Web", Conservation Biology in Practice 2(4): 25.

Pauly, D., Watson, R. and Alder, J. (2005) "Global Trends in World Fisheries: Impacts on Marine Ecosystems and Food Security", Philosophical Transactions of The Royal Society of London B-Biological Sciences 360(1453) (Jan. 29): 5-12.

Pauly, D. and Maclean, J. L. (2003) In a Perfect Ocean: the State of Fisheries and Ecosystems in the North Atlantic Ocean. Washington, DC: Island Press.

Perry, I. R. and Ommer, R. E. (2003) "Scale Issues in Marine Ecosystems and Human Interactions", Fisheries Oceanography 12(4-5): 513-22.

Pitcher, T. (2005) "Back-to-the-Future: a Fresh Policy Initiative for Fisheries and a Restoration Ecology for Ocean Ecosystems", Philosophical Transactions of The Royal Society of London B-Biological Sciences 360(1453): 107.

Pitcher, T.J. and Hart, P.J.B. (1995) The Impact of Species Changes in African Lakes . London: Chapman and Hall.

Pitcher, T.J., Heymans, S.J.J., Ainsworth, C., Buchary, E.A, Sumaila, U. R. and Christensen, V. (2004) "Opening the Lost Valley: Implementing a 'Back to the Future' Restoration Policy for Marine Ecosystems and their Fisheries", in E.E. Knudsen, D.D. MacDonald and J.K. Muirhead (eds), Sustainable Management of North American Fisheries. Bethesda, MD: American Fisheries Society Symposium, pp. 173-201.

Pitcher, T.J. and Pauly, D. (1998) "Rebuilding Ecosystems, not Sustainability, as the Proper Goal of Fishery Management", in T.J. Pitcher, B. Hart and D. Pauly (eds) Reinventing Fisheries Management, pp. 311-29. London: Chapman and Hall. 
Rivoirard, J., Simmonds, E., Foote, K., Fernandes, P. and Bez, N. (2000) Geostatistics for Estimating Fish Abundance . Oxford: Blackwell Science.

Roberts, C., Hawkins, J. and Gell, F. (2005) "The Role of Marine Reserves in Achieving Sustainable Fisheries", Philosophical Transactions of The Royal Society of London B-Biological Sciences 360(1453): 123.

Roberts, C. M., Hawkins, J.P., Chapman, N., Clarke, V., Morris, A.V., Miller, R. and Richards, A. (1998) The

Threatened Status of Marine Species, a Report to the World Conservation Union (IUCN) Species Survival

Commission, and Center for Marine Conservation, Washington, D.C. Gland: IUCN,

Rozwadowski, H. M. (2002) The Sea Knows no Boundaries: a Century of Marine Science under ICES . Seattle: ICES (International Council for the Exploration of the Sea) in association with University of Washington Press.

Smith, P.J. (1999) "Genetic Resources and Fisheries: Policy Aspects", in R.S.V. Pullin, D.M. Bartley and J.

Kooiman (eds) Towards Policies for Conservation and Sustainable Use of Aquatic Genetic Resources , pp. 43-62.

Manila: ICLARM (International Center for Living Aquatic Resources Management) Conference Proceedings, 59.

Valavanis, V.D. (2002) Geographic Information Systems in Oceanography and Fisheries ; London: Taylor and Francis and Spon Press.

Walters, C. J., Christensen, V., Martell, S. J. and Kitchell, J. F. (2005) "Possible Ecosystem Impacts of Applying MSY Policies from Single-Species Assessment", ICES Journal of Marine Science 62(3) (May): 558-68.

Walters, C. J. and Juanes, F. (1993) "Recruitment Limitation as a Consequence of Natural-Selection for Use of Restricted Feeding Habitats and Predation Risk-Taking by Juvenile Fishes", Canadian Journal of Fisheries and Aquatic Sciences 50(10) (Oct.): 2058-70.

Walters, C.J. and Martell, S. J. D. (2004) Fisheries Ecology and Management . Princeton: Princeton University Press.

Walters, C. J., Christensen, V. and Pauly, D. (2002) "Searching for Optimum Fishing Strategies for Fisheries Development, Recovery and Sustainability', in T.J. Pitcher and K. Cochrane (eds) The Use of Ecosystems Models to 
Investigate Multispecies Management Strategies for Capture Fisheries, pp. 11-5. Vancouver: Fisheries Centre Research Reports 10(2), 156 pp.

Watson, R. and Pauly, D. (2001) "Systematic Distortions in World Fisheries Catch Trends', Nature 414: 534-36.

Wilkinson, C. (ed.) (2004) Status of Coral Reefs of the World: 2004 . Townsville: Australian Institute of Marine Science.

Wright, D. J. (1999) "Down to the Sea in Ships: the Emergency of Marine GIS', in D. J. Wright and D. J. Bartlett (eds) Marine and Coastal Geographical Information System . London: Taylor and Francis.

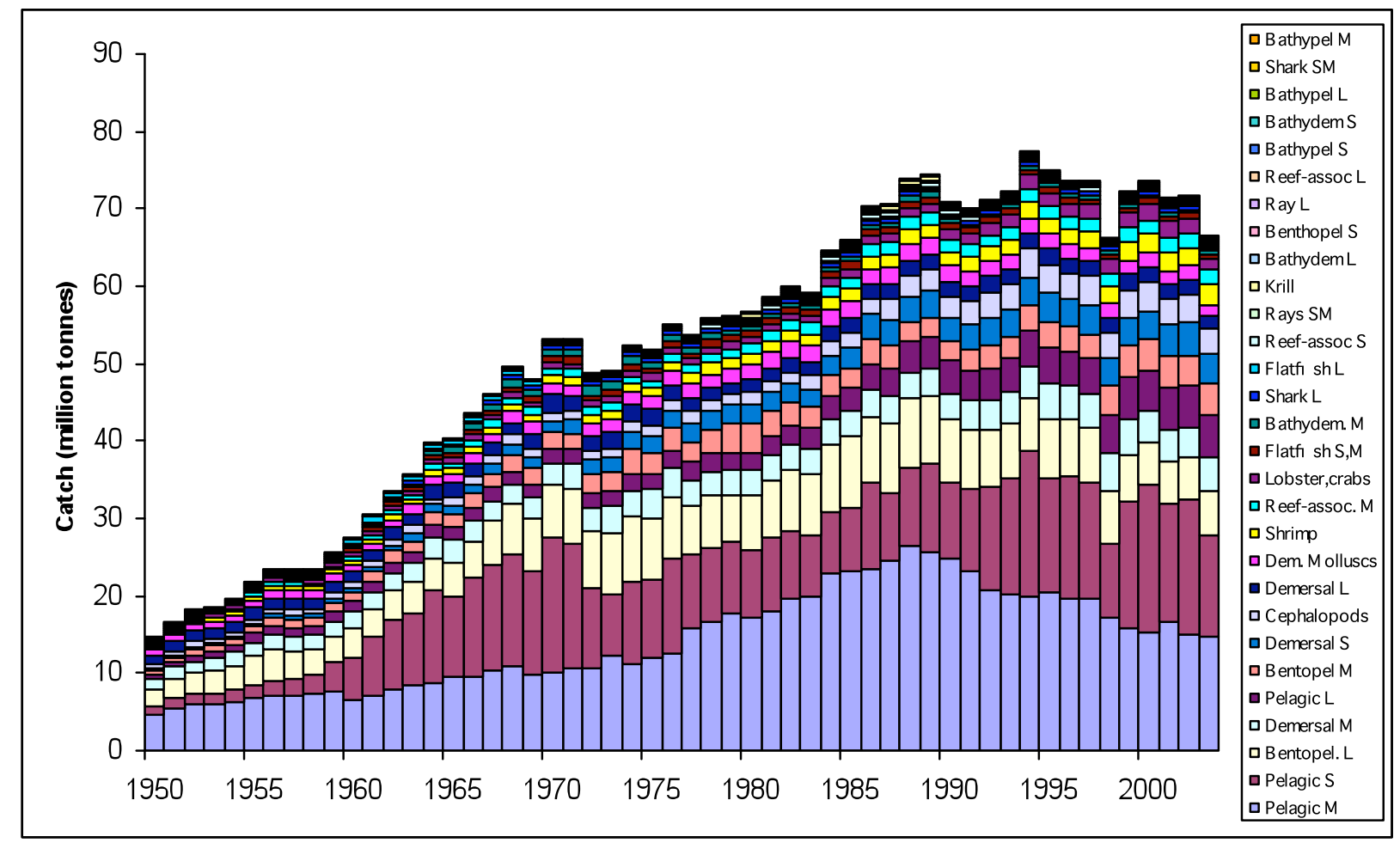

Figure 1. Trends in global catches by catch categories since 1950. Catches increased through the first three to four decades, stagnated, and have been declining since. S, M, and L are small, medium and large, with cuts at $\mathrm{L}_{\omega}$ of 30 and $90 \mathrm{~cm}$. Data source: www.seaaroundus.org. 


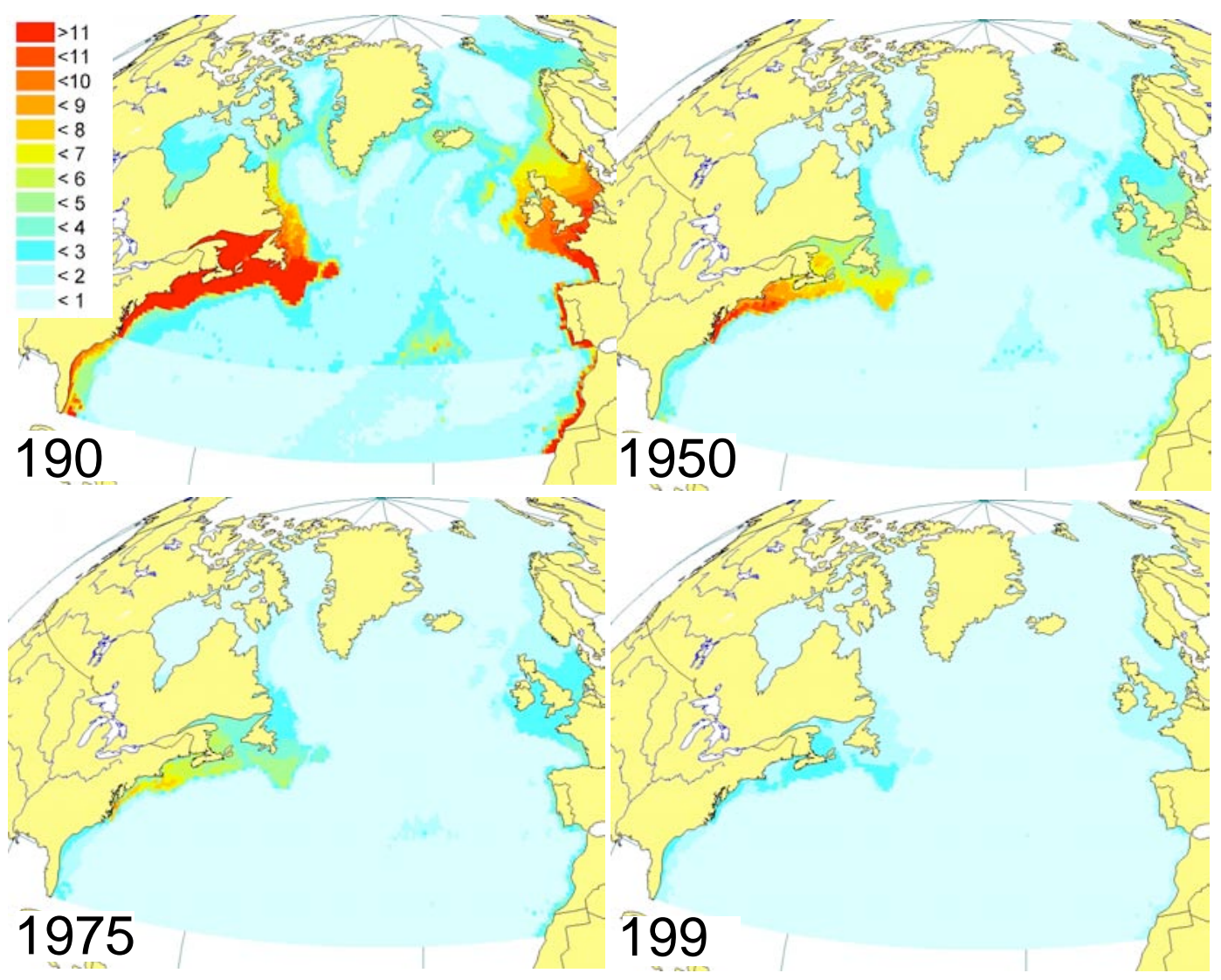

Figure $3_{-}$, Spatial estimates of combined biomass of high-trophic level fishes ('tablefish') in the North Atlantic through the $20^{\text {th }}$ Century. Unit for legend in $\mathrm{t} \cdot \mathrm{km}^{-2}$. (Christensen, Guénette, Heymans, Walters, Watson, Zeller and Pauly, 2003). 


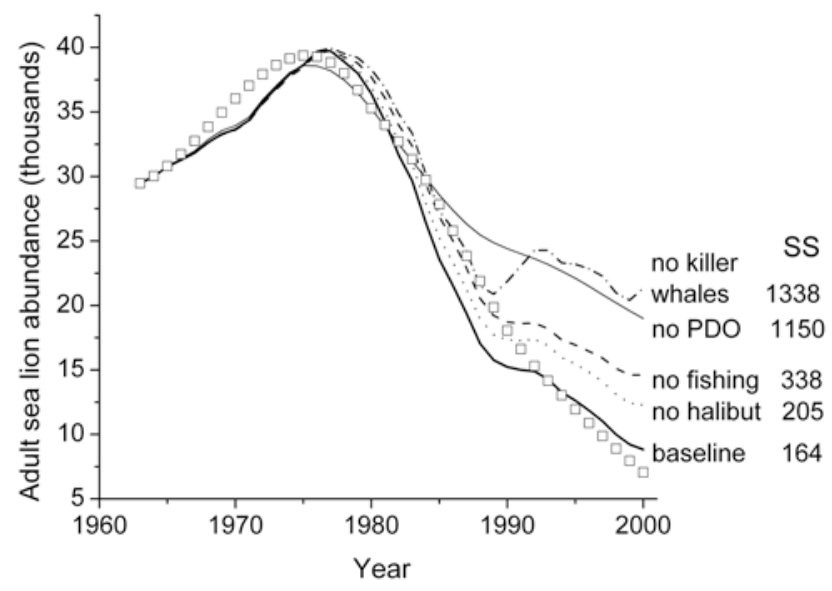

Figure 5 , Simulated impact of not considering impact of predation (killer whales), ocean productivity

(PDO), fishing and competition from flatfish (halibut). The baseline run includes all these drivers, while the observed time series is indicated by squares (Guénette, Heymans, Christensen and Trites 2006) 


\section{Central North Pacific}
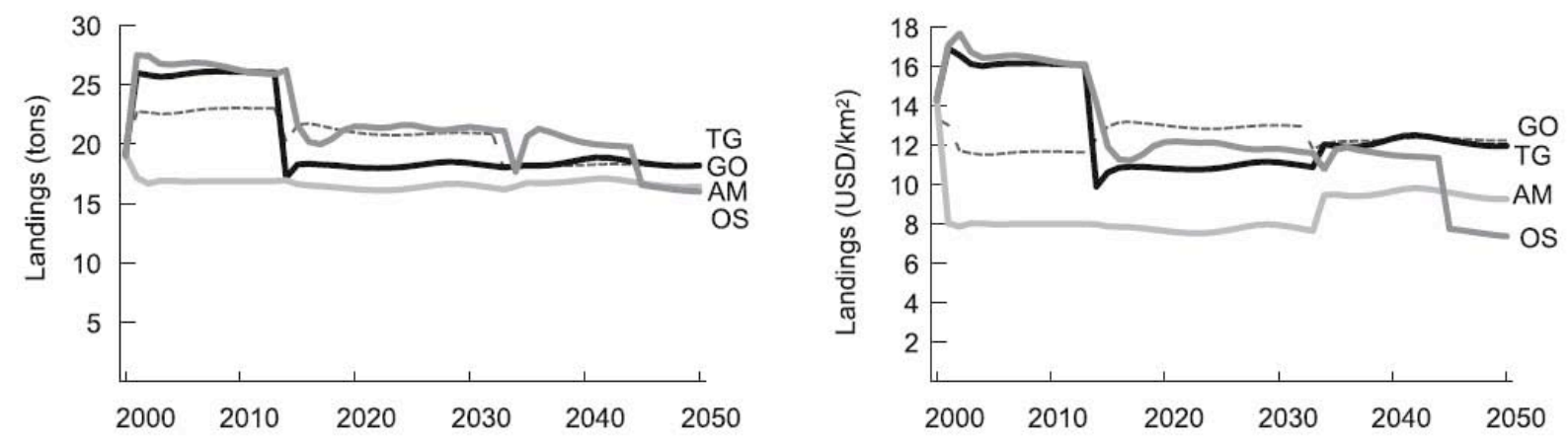

Figure 7. Comparison of fish landings in the central North Pacific for four MA scenarios based on EwE

modeling. Scenario names: AM: Adapting Mosaic; GO: Global Orchestration; OS: Order from Strength; TG: TechnoGarden. Source: Millennium Ecosystem Assessment, Volume 2, Chapter 9. 